\title{
ANTARCTIC AND SOUTHERN OCEAN SEA-ICE AND CLIMATE TRENDS
}

\author{
by
}

\author{
T.H. Jacka
}

(Australian Antarctic Division, Kingston, Tasmania 7050, Australia)

\section{ABSTRACT}

A computer-based climate monitoring project is described. Data sets include monthly and annual mean surface temperatures and pressures for occupied stations in Antarctica, the Southern Ocean and South Pacific Ocean: and monthly Antarctic sea-ice extent at each $10^{\circ}$ of longitude.

Simple statistical analyses of the data sets reveal a mean warming of $\sim 0.15^{\circ} \mathrm{C}(10 \mathrm{a})^{-1}$ since the mid $1950 \mathrm{~s}$ for Antarctic coastal stations and of $\sim 0.04^{\circ} \mathrm{C}(10 \mathrm{a})^{-1}$ since the mid 1940s for the ocean stations. The sea-ice record from 1973 to 1988 reveals that the average northern ice limit has decreased at $\sim 0.23^{\circ}$ lat. $(10 \mathrm{a})^{-1}$. Despite apparently compatible long-term trends of temperature and sea-ice extent, annual fluctuations of temperature and ice extent are highly variable and are not well correlated.

\section{INTRODUCTION}

The possibility of global climatic change prompted by increased atmospheric greenhouse gas concentrations has led to several studies of the various climatic parameters and of their relationships (e.g. Schwerdtfeger and Kachelhoffer, 1973; Streten and Pike, 1980; Cavalieri and Parkinson, 1981). In polar regions the study of sea-ice characteristics has gained new significance because positive feedback mechanisms involving changes in the ice cover may amplify small climatic fluctuations. Sea-ice changes may thus be a particularly sensitive indicator of climatic change.

Climate monitoring projects are essential to supply researchers with the raw data scts required for studies of recent climatic change. The first aim of this paper is to advertise currently available data sets (i.e. to announce their availability to other researchers). The data sets available (hard copy or on magnetic tape) have been described in part by Jacka (1983) and Jacka and others (1984) and they include:

- Antarctic sea-ice extent: the northern ice edge from one U.S. Navy/NOAA Joint Ice Center map per month is digitized at each $10^{\circ}$ of longitude. Record length is January, 1973 to July, 1989 and the data are updated monthly. In addition, some data have been digitized from Cook's expeditions (summer months of 1772 to 1775), the Discovery expeditions ( 1930) and from minimum-brightness composite photographs for the period 1967 to 1972.

- Monthly mean surface temperature: monitored stations include all occupied Antarctic stations, all occupied Southern Ocean stations, a selection of more northerly stations in the South African and Australian regions and a selection of South Pacific Ocean island stations. Record length is commencement of measurement to 1989 (where available). For a few stations where the measurements commenced prior to 1901 , the record commences at 1901 . Data are updated as they become available.

- Monthly mean surface air pressure: monitored stations are the same as included in the surface temperature list. For inland Antarctic stations, station level pressures are recorded. For all other stations, sea level pressures are recorded. Data are updated as they become available. This data set is still in the process of being checked for accuracy and is expected to be available within the next year.

The second aim of this paper is to present some of the simpler statistical calculations which have been performed on the data to obtain an idea of trends and of possible relations between sea-ice extent and climatic temperature fluctuations.

\section{DATA SOURCES}

Mean monthly surface temperature data are collected from several publications emanating from countries responsible for the operation of the various meteorological stations. Examples of these publications include Antarctic Journal of the United States, the Japanese Antarctic Bulletin, Information Bulletin of Soviet Antarctic Expeditions, the Australian ANARE News, New Zealand's Meteorological Observations published annually and the monthly climate data summary from South Africa. In addition, Monthly Climatic Data of the World and Climate Monitor include summaries for several Antarctic and Southern Ocean stations. The excellent data set published by Jones and Limbert (1987) has been used to check and to fill in some gaps in the set. Finally and where necessary, data are obtained by personal communication with observers at the stations themselves.

It should be noted that the mean monthly temperature recorded by most climate stations is half the sum of the mean minimum and mean maximum temperature. Unfortunately, there has not always been consistency in the data published by the various meteorological authorities.

Sea-ice extent from the U.S. Navy/NOAA Joint Ice Center weekly mans are monitored on a monthly basis. Computer-linked digitization of these maps is of the northern ice limit at each $10^{\circ}$ of longitude. The Joint Ice Center maps have been available in the current format since January, 1973 and are compiled from various sources (Godin, 1979). Data from visible and infrared wavelength radiometers on NOAA and Defence Mapping Satellite Program (DMSP) polar orbiting satellites, and passive microwave images from the Electrically Scanning Microwave Radiometer on board NASA's Nimbus 5 and from the Scanning Multichannel Microwave Radiometer on board Nimbus 7 and now on the DMSP series provide the bulk of the data. Ship-board and aerial data are also used to supplement the above, particularly during the summer months.

Prior to the Joint Ice Center's provision of weekly maps, minimum-brightness composite photographs for the period 1967 to 1972 gave the first regular description of the broad-scale Antarctic sea-ice characteristics. Earlier less regular descriptions of the broad-scale sea-ice extent are obtained from Tolstikov and others (1966), Atlas Antarktiki which was compiled using data mainly from the period 1947 to 1962; from the British Admiralty (1943), Ice Chart of the Southern Hemisphere; and from the U.S. Navy Hydrographic Office (1957), Oceanographic Atlas of the Polar Seas. Earlier data are obtained from the scientific observations of the Discovery and from whaling expeditions 

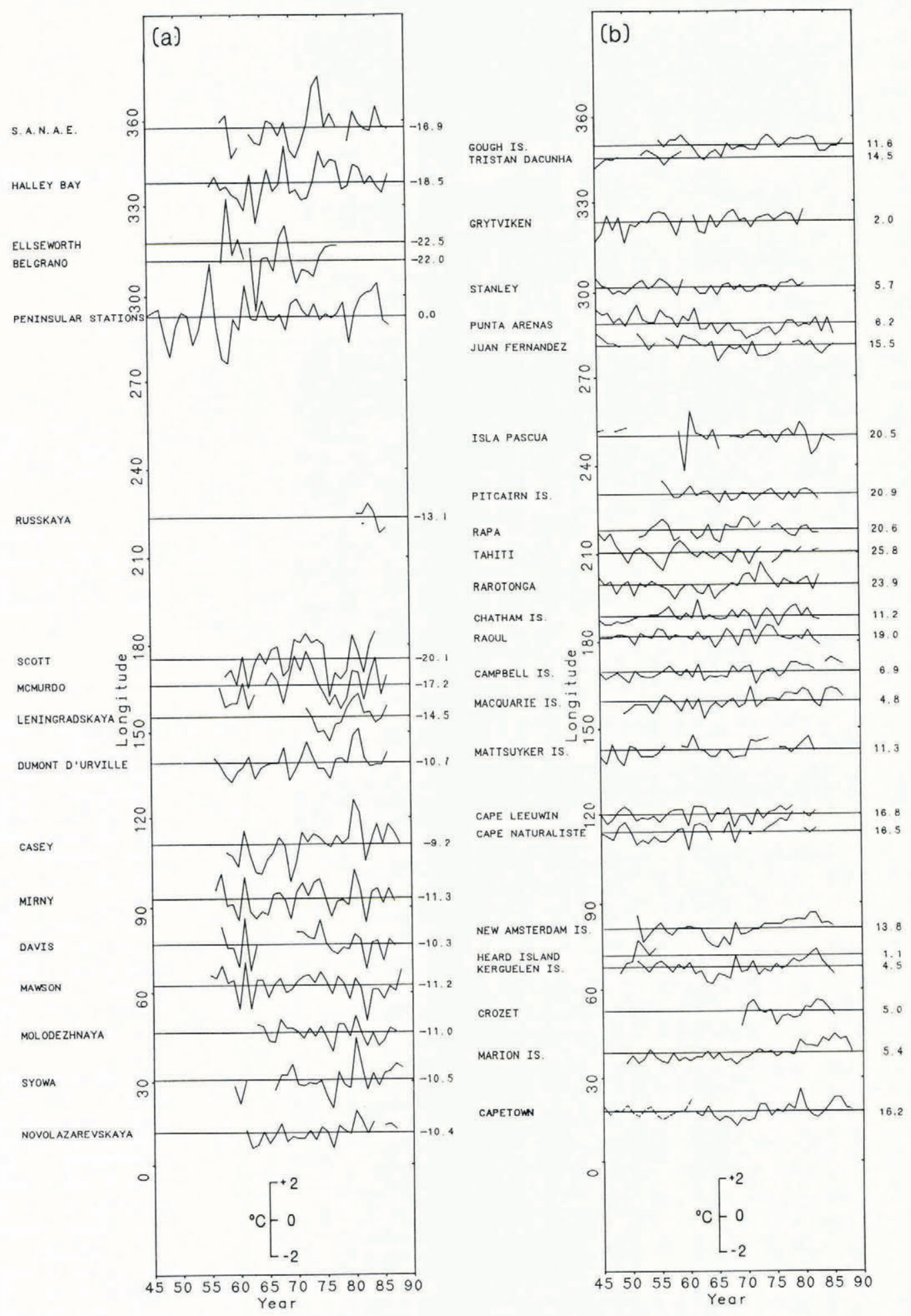

Fig. 1. Annual mean surface temperatures for (a) coastal Antarctic stations and (b) Southern Ocean and South Pacific Ocean stations.

during the late 1920s and early 1930s (Mackintosh and Herdman, 1940). Finally, some 18th century data are available from the observations of Cook and of Bellingshausen (Herdman, 1959; Rubin, 1982a, b) which provide some descriptions of sea-ice extent during summer months.

\section{ANTARCTIC AND SOUTHERN OCEAN TEMPERATURE TRENDS}

Annual mean temperatures for coastal Antarctic stations and for Southern Ocean and South Pacific Ocean stations are plotted in Figures $1 \mathrm{a}$ and $\mathrm{b}$, respectively. Within these figures, the stations are arranged longitudinally, so that temperature trends may be studied in both space and time domains. Figure la includes one plot for Antarctic Peninsula stations. This plot has been compiled by calculating the mean of the temperature anomalies at each Peninsula station for each year. The South Pacific Ocean stations are included in Figure $1 \mathrm{~b}$ because there are no stations in this sector of the Southern Ocean. Furthermore, only Russkaya, with a record length of six years, is in this sector of coastal Antarctica.

It is apparent from Figure 1 that a slight warming trend is exhibited for both the coastal Antarctic and Southern Ocean data sets. Applying a linear least-squares fit to each of the station data, a positive slope is indicated for the data from all Antarctic stations except Molodezhnaya, Mawson and Davis, and from all Southern Ocean stations, but not for the South Pacific Ocean stations. The slopes of the least-squares lines (i.e. the average 


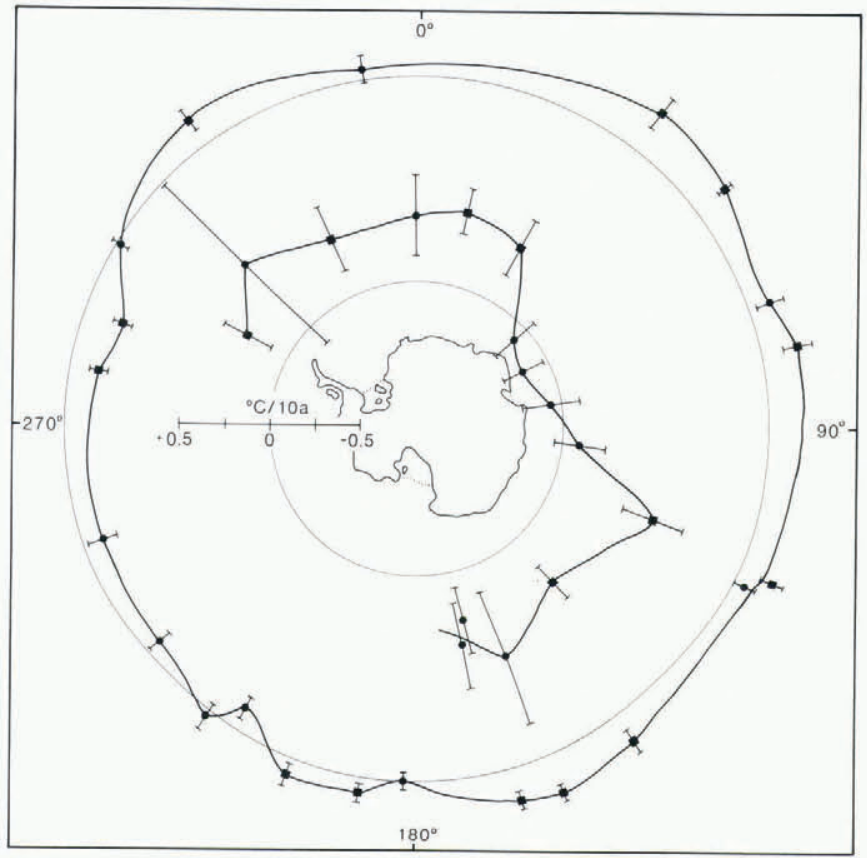

Fig. 2. Average warming rate for coastal Antarctic stations (plotted about the small circle) and Southern and South Pacific ocean stations (plotted about the larger circle). Points marked with squares indicate t-test significance levels of $90 \%$ or greater. Intervals marked on each point indicate standard deviations of the slope calculations.

warming rates over the observation period) are plotted in Figure 2 about the small circle for the Antarctic stations and about the larger circle for the Southern Ocean and South Pacific Ocean stations. t-test significance levels of the least-squares fits of $90 \%$ or greater, and standard deviations of the slope circulations, are indicated.

The cooling trend exhibited by stations in the Enderby Land/Prydz Bay area of Antarctica seems compatible with the gridded analysis of station seasonal temperature differences plotted by Jones and Wigley (1988). The warming trend exhibited by coastal Antarctic stations is generally greater than that for Southern Ocean stations. The warming rate exhibited by the mean temperature anomaly

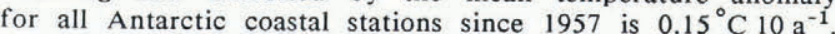
For the ocean stations, the mean warming rate since 1945 is $0.04^{\circ} \mathrm{C} 10 \mathrm{a}^{-1}$.

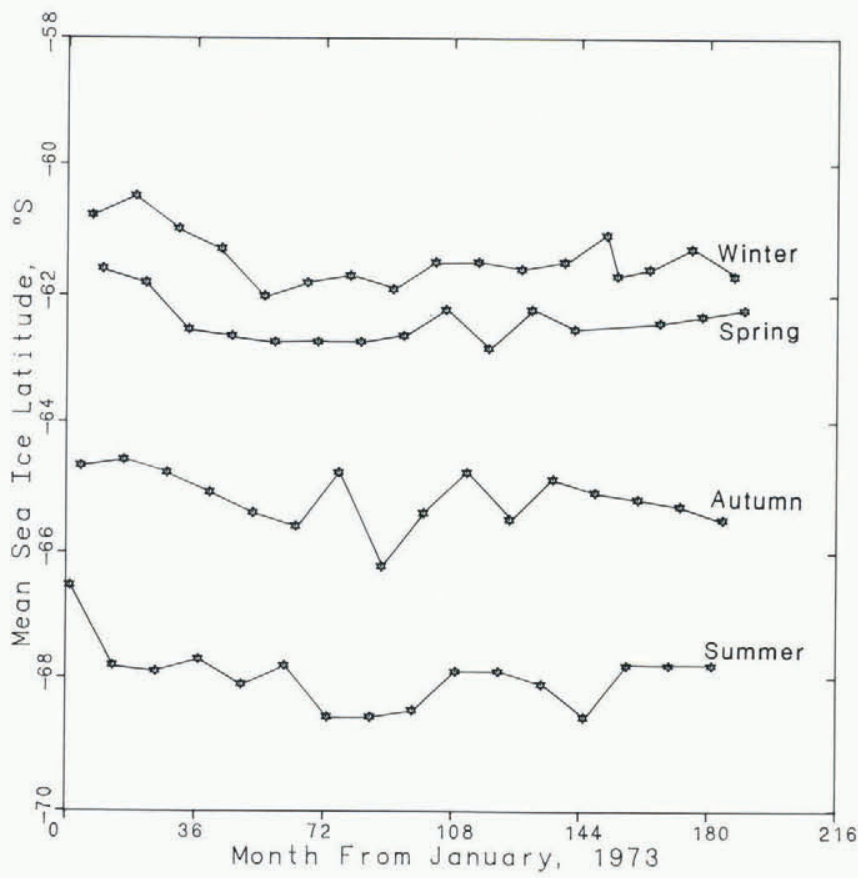

Fig. 3. Mean Antarctic sea-ice extent for each season for the period 1973 to 1988 .

\section{ANTARCTIC SEA-ICE EXTENT TRENDS}

Figure 3 displays mean Antarctic sea-ice extent trends for each season from 1973 to 1988. The summer, autumn and winter data exhibit decreases in the sea-ice extent of $\sim 0.3^{\circ}$ lat. $10 \mathrm{a}^{-1}$ and in each case the linear least-squares fit is significant at the $80 \%$ level. The spring data indicate no significant decrease. A decrease in winter ice extent, but not in spring extent, is compatible with a tendency to later occurrence of the maximum ice extent (cf. Gloersen and Campbell, 1988). Data from Cook's expeditions of 1772 to 1775 and from the Discovery expeditions in the 1930s indicate for the summer months that there has been a decrease in sea-ice extent. Historical sea-ice extent data have been studied in greater detail by Parkinson (this volume).

\section{COMPARISON OF TEMPERATURE AND SEA-ICE EXTENT TRENDS}

Comparison of the mean sea-ice extent data with the two mean temperature data sets over the period 1973 to 1988 (Fig. 4) reveals that for a few selected years (note, particularly, 1980) high Antarctic temperatures associated with decreased sea-ice extent. However, comparisons of the

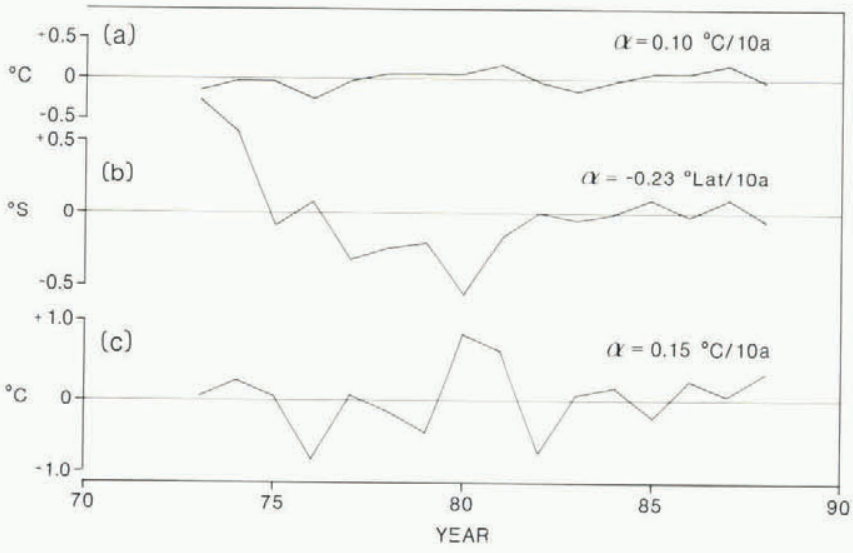

Fig. 4. For the period 1973 to 1988, means across all longitudes of (a) ocean station mean temperature anomaly, (b) annual sea-ice extent, and (c) coastal Antarctic station mean temperature anomaly. $\alpha$ indicates the slope of a linear least-squares fit through each data set over this time period.

whole record do not indicate close correlation. Jacka (1981) found that the sea-ice extent was better correlated with temperature if an eastward shift of the sea ice of $\sim 30^{\circ}$ was imposed (cf. Lemke and others, 1980, who related sea-ice drift to the west-to-east flowing circumpolar current).

Over the total data record, a sea-ice extent decrease of $0.23^{\circ}$ lat. $(10 \mathrm{a})^{-1}$ with an Antarctic temperature increase of $0.15^{\circ} \mathrm{C}(10 \mathrm{a})^{-1}$, along with the assumption that these phenomena are dependent, implies a long-term change in sea-ice extent of $1.53^{\circ}$ lat. ${ }^{\circ} \mathrm{C}^{-1}$ (cf. Budd, 1975, who found for data at Laurie Island a relation between sea-ice and temperature fluctuations equivalent to $\sim 2.0^{\circ}$ lat. ${ }^{\circ} \mathrm{C}^{-1}$ ).

\section{SUMMARY AND FURTHER REMARKS}

1. A warming trend is exhibited by most of the Antarctic and Southern Ocean station temperatures since the majority of records began in the late 1950s. A slight cooling is exhibited in the Enderby Land/Prydz Bay region of Antarctica and in the South Pacific Ocean. On average the warming trend for Antarctic stations is $\sim 0.15^{\circ} \mathrm{C}(10 \mathrm{a})^{-1}$ and for the Southern Ocean stations is $\sim 0.04^{\circ} \mathrm{C}(10 \mathrm{a})^{-1}$.

2. There is no significant correlation between the annual temperature data and Antarctic sea-ice extents. However, associated with the long-term warming during the period 1973 to 1988 there has been a trend to reduced sea-ice extent (exhibited in all seasons except spring) of $\sim 0.23^{\circ}$ lat. $(10 a)^{-1}$. 
Recent studies have shown that (a) the northern extent of the East Antarctic sea ice is strongly influenced by ice drift (Allison, 1989; Wadhams and others, 1989) while air temperature perhaps affects the rate of production and growth of ice within the seasonal ice zone, and (b) there are large areas of thin ice within the seasonal sea-ice zone (Ackley and Smith, 1983; Jacka and others, 1987; Allison, 1989; Brandt and others, this volume).

For studies therefore of sea-ice/climate relationships it may be equally important to examine the concentrations and thicknesses of the ice within the seasonal sea-ice zone rather than just the ice extent. In particular, there is a need to examine ice concentrations and thicknesses during the winter and spring when the ice is at maximum extent. Expeditions to Antarctic waters for ship-based field observations along with data from drifting buoys and satellite remote sensing will hopefully allow clearer monitoring of sea-ice thicknesses and concentrations, and of climatological parameters within the seasonal ice zone.

\section{ACKNOWLEDGEMENT}

I thank K. Mavrakis for assistance with data monitoring and computer graphics.

\section{REFERENCES}

Ackley, S.F. and S.J. Smith. 1983. Sea ice observations. Reports of the U.S.-U.S.S.R. Weddell Polynya Expedition, October-November 1981. Vol. 5. CRREL Spec. Rep. 83-2.

Allison, I. 1989. Pack-ice drift off East Antarctica and some implications. Ann. Glaciol., 12, 1-8.

Brandt, R., I. Allison, and S. Warren. 1990. Albedo of young and first-year Antarctic ice. Ann. Glaciol., 14, 331.

British Admiralty. 1943. Ice chart of the Southern Hemisphere (5032). London, Naval Meteorological Branch. Hydrographic Department.

Budd, W.F. 1975. Antarctic sea-ice variations from satellite sensing in relation to climate. J. Glaciol., 15(73), 417-427.

Cavalieri, D.J. and C.L. Parkinson. 1981. Large-scale variations in observed Antarctic sea ice extent and associated atmospheric circulation. Mon. Weather Rev., 109(11), 2323-2336.

Gloersen, P. and W.J. Campbell. 1988. Variations in the Arctic, Antarctic, and global sea ice covers during 19781987 as observed with the Nimbus 7 scanning multichannel microwave radiometer. J. Geophys. Res., 93(C9), 10,666-10,674.

Godin, R.H. 1979. Data sources and sea ice products of Fleet Weather Facility/Joint Ice Center, Suitland. Glaciological Data. Report GD-5, 29-35.
Herdman, H.F.P. 1959. Early discoverers. XII. Some notes on sea ice observed by Captain James Cook, R.N., during his circumnavigation of Antarctica, 1772-75. J. Glaciol., 3(26), 534-541.

Jacka, T.H. 1981. Antarctic temperature and sea ice extent studies. In Young, N.W., comp. Antarctica: weather and climate. Preprint volume of conference sponsored by Royal Meteorological Society Australian Branch. Melbourne, University of Melbourne, unpaged.

Jacka, T.H. 1983. A computer data base for Antarctic sea ice extent. ANARE Res. Notes, 13.

Jacka, T.H., L. Christou, and B.J. Cook. 1984. A data bank of mean monthly and annual surface temperatures for Antarctica, the Southern Ocean and South Pacific Ocean. ANARE Res. Notes, 22.

Jacka, T.H., I. Allison, R. Thwaites, and J.C. Wilson. 1987. Characteristics of the seasonal sea ice of East Antarctica and comparisons with satellite observations. Ann. Glaciol., 9, 85-91.

Jones, P.D. and D.W.S. Limbert. 1987. A data bank of Antarctic surface temperature and pressure data. Report TRO38 prepared for United States Department of Energy.

Jones, P.D. and T.M.L. Wigley. 1988. Antarctic gridded sea level pressure data: an analysis and reconstruction back to 1957. J. Climate, 1(12), 1199-1220.

Lemke, P., E.W. Trinkl, and K. Hasselmann. 1980. Stochastic dynamic analysis of polar sea ice variability. $J$. Phys. Oceanogr., 10(2), 2100-2120.

Mackintosh, N.A. and H.F.P. Herdman. 1940. Distribution of the pack-ice in the Southern Ocean. Discovery Rep., 19, 285-296.

Parkinson, C.L. 1990. Search for the Little Ice Age in historical sea ice records. Ann. Glaciol., 14, 221-225.

Rubin, M.J. 1982a. James Cook's scientific programme in the Southern Ocean, 1772-75. Polar Rec., 21(130), 33-49.

Rubin, M.J. 1982b. Thaddeus Bellingshausen's scientific programme in the Southern Ocean, 1818-21. Polar Rec., 21(132), 215-229.

Schwerdtfeger, W. and S.J. Kachelhoffer. 1973. The frequency of cyclonic vortices over the Southern Ocean in relation to the extension of the pack belt. Antarct. $J$. U.S., 8(5), 234.

Streten, N.A. and D.J. Pike. 1980. Characteristics of the broadscale Antarctic sea ice extent and the associated atmospheric circulation, 1972-1977. Arch. Meteorol. Geophys. Bioklimatol., Ser. B., 29(3), 279-299.

Tolstikov, Ye.I., ed. 1966. Atlas Antarktiki I [Atlas of Antarctica I]. Moscow, Glavnoye Upravleniye Geodezii i Kartografii.

U.S. Naval Hydrographic Office. 1957. Oceanographic atlas of the polar seas. Part I. Washington, DC, U.S. Naval Hydrographic Office. (Antarctic Publication 705.)

Wadhams, P., C.B. Sear, D.R. Crane, M.A. Rowe, S.J. Morrison, and D.W.S. Limbert. 1989. Basin-scale ice motion and deformation in the Weddell Sea during winter. Ann. Glaciol., 12, 178-186. 